Annals of Warsaw University of Life Sciences - SGGW

Land Reclamation No 41, 2009: 49-56

(Ann. Warsaw Univ. of Life Sci. - SGGW, Land Reclam. 41, 2009)

\title{
Spatial distribution of bottom sediment deposits in water reservoirs at Zesławice
}

\author{
BOGUSŁAW MICHALEC ${ }^{1)}$, KAROL PĘCZEK $^{2)}$, MATEUSZ STRUTYŃSKI ${ }^{3)}$ \\ 1), 3) Department of Water Engineering, Agriculture University in Cracow \\ ${ }^{2)}$ FWK-Air Sp.z.o.o. in Cracow
}

\begin{abstract}
Spatial distribution of bottom sediment deposits in water reservoirs at Zestawice. Spatial distributions of bottom sediment deposits in two small water reservoirs located on the River Dłubnia at Zesławice is presented in this paper. The distribution was elaborated according to Dendy's method on the basis of results of silting measurements performed in the 2005. Horizontal and vertical distribution of sediment deposits was shown as relation between the relative volume of deposited sediments $\left(\mathrm{S}_{\mathrm{h}} / \mathrm{S}\right)$ and relative storage capacity of the reservoir $\left(\mathrm{V}_{\mathrm{h}} / \mathrm{V}\right)$; the vertical distribution of sediment deposits was presented as relation between the relative volume of deposited sediments $\left(\mathrm{S}_{\mathrm{v}} / \mathrm{S}\right)$ and relative reservoir depth $\left(\mathrm{D} / \mathrm{D}_{\mathrm{m}}\right)$. On the basis of performed analysis of
\end{abstract} horizontal distributions of sediment deposits it was stated that in the main reservoir at Zesławice $58 \%$ of the sediment trapped in the reservoir was accumulated in the inflow (upstream part of the reservoir, whose relative volume is 0.25 ). In the inflow section of the assistant reservoir of relative storage capacity equal 0.22 only $29 \%$ of the sediment was deposited. Comparing curves of horizontal sediment deposits distribution in the main reservoir in its inflow part according to measurement data from the 2005 and 1986 i.e. from a comparable period of operation before desilting and building of an assistant reservoir it was stated that relative volumes of sediment trapped after desilting are over $40 \%$ higher than before desilting. In a comparable period of operation before desilting (measurement in the 1983) and after desilting (measurements in the 2005) i.e. after seventeen and sixteen years respectively in the main reservoir the accumulated sediments formed an isle - the value $\mathrm{S}_{\mathrm{v}} / \mathrm{S}$ equaling 0.09 for $D / D_{m}$ equal 0 in consequence of a change of hydraulic conditions of water and sediment flow
- due to a part of inflowing water of the River Dłubnia being directed to the assistant reservoir.

Key words: sediment, small water reservoir, silting, spatial distribution of sediment.

\section{INTRODUCTION}

In consequence of silting intensity the operation period of small water reservoirs is considerably shorter than a big water reservoirs. The sediment accumulated in the reservoirs causes elevation of the bottom reducing the available storage capacity of the reservoir, influencing negatively changes of water quality, and active negatively on the esthetic aspect of the object itself and adjacent territory. Deposition of sediments in water reservoirs is one of the main factors limiting their proper operation. A specially significant aspect of analysis and appraise of the silting process in determination of sediment deposits distribution on the reservoir bottom. Determination of distribution of sediments on the water reservoir bottom is of particular importance in ensuring proper work of water intakes. The crucial problem lies not only in the reservoir silting intensity but also in proper functioning of installations and associated objects. Recognition 
of spatial distribution of sediments accumulated in small water reservoirs may prove helpful at the designing stage. Recognition of sediment distribution permits proper evaluation of efficiency of the investment, proper location of installations and associated objects as well as choice of methods of sediment removal.

In world publications analysis of sediment deposits in big water reservoirs is focused on. Among the methods of forecasting sediment deposits distribution in big water reservoirs one may mention the empiric method Area - Increment Method (AIM) elaborated by Chrisofano in 1953 (Batuca, Jordaan 2000), or the popular method elaborated in 1958 by Borland - Miller (Empirical Area - Reduction Method - EARM) which was developed on the basis of results of silting measurements of 30 water reservoirs of storage capacity from $49 \mathrm{mln} \mathrm{m}^{3}$ to $37 \mathrm{mln} \mathrm{m}^{3}$ (Dąbkowski et al. 1982). Investigations of spatial distribution of sediment deposits in big water reservoirs were carried also by Rooseboom and Annandale (Batuca, Jordaan 2000). Among the scarce publications concerning distribution of bottom sediments in small water reservoirs Dendy's (1974, 1982) publications should be distinguished. In this publications he presented the method of spatial bottom sediment distribution in water reservoirs of storage capacity from 20 thousand $\mathrm{m}^{3}$ to $1.7 \mathrm{mln} \mathrm{\textrm {m } ^ { 3 }}$.

This paper aims at presentation of spatial distribution of sediment deposits in small water reservoirs at Zesławice on the River Dłubnia elaborated according to Dendy's method.

\section{MATERIAL AND METHODS}

In the 1983, after seventeen years of operation over $50 \%$ silting was found. Before desilting of the main reservoir an assistant reservoir was built (Fig. 1). Its building started in 1986 and in 1997 it was handed over for operation. The aim of the assistant reservoir was to take over the function of the main reservoir in time of its desilting which took place in the 1989.

The volume of deposited sediments in the investigated water reservoirs was determined on the basis of direct measurements in cross sections by means of a sounding rod. Measurements were taken in cross-sections and by use of the method of dissipated points. Distribution of cross-sections is presented in Figure 1. Results of depth measurements in the reservoirs were plotted on cross-sections. Subsequently the surfaces of deposits in sections were determined and the volume of deposited sediments in the reservoir was calculated.

Onthe basis of results ofmeasurements performed in the 2005 spatial distribution of sediments was analysed. The method presented in Dendy's (1974, 1981) papers was applied for determination of horizontal and vertical distribution of sediments deposited in the investigated water reservoirs. The horizontal sediment distribution in the reservoir was described as the relation between the relative volume of deposited sediment $\left(\mathrm{S}_{\mathrm{h}} / \mathrm{S}\right)$ and the relative volumetric capacity of the reservoir $\left(\mathrm{V}_{\mathrm{h}} / \mathrm{V}\right)$. The relative volume of deposited sediments was determined as the relation between the relative volume of deposited sediments $\left(\mathrm{S}_{\mathrm{h}}\right)$ present at 


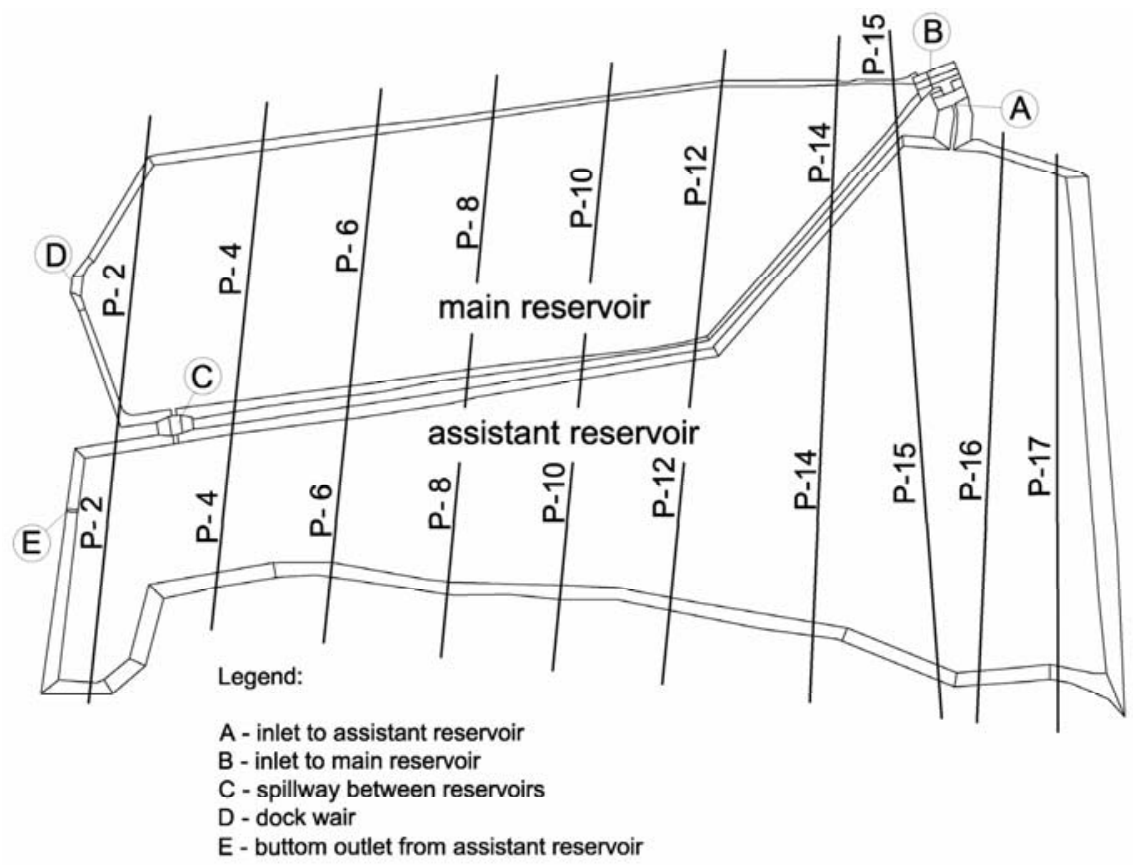

FIGURE 1. Main and assistant water reservoir at Zesławice P-2 - P-18 measuring sections

a given distance from the inflow into the reservoir and the total volume of sediments (S), whereas the relative volumetric capacity of the reservoir was determined as the relation between the volumetric capacity of the part of the reservoir $\left(\mathrm{V}_{\mathrm{h}}\right)$ being at a given distance from the inflow into the reservoir and the total volumetric capacity of the reservoir $(\mathrm{V})$. The relative volumes of sediment deposits $\left(\mathrm{S}_{\mathrm{h}} / \mathrm{S}\right)$ and the relative volumetric capacities of the reservoir $\left(\mathrm{V}_{\mathrm{h}} / \mathrm{V}\right)$ were given for consequent crosssections of the reservoir starting from its inflow. Vertical distribution of sediment deposits was presented as relation between the relative volume of sediment deposits $\left(\mathrm{S}_{\mathrm{v}} / \mathrm{S}\right)$ and the relative depth of the reservoir $\left(\mathrm{D} / \mathrm{D}_{\mathrm{m}}\right)$. The relative volume of sediment deposits was determined as the relation between the sediment deposits volume $\left(\mathrm{S}_{\mathrm{v}}\right)$ found in the sediment layer below the determined level and the total sediment volume (S), whereas, the relative depth of the reservoir was determined as the relation between the depth (D) and the maximal depth of the reservoir $\left(D_{m}\right)$.

\section{RESULTS AND DISCUSSION}

The volume of the sediment trapped in the main water reservoirs and in the assistant one was determined on the basis of silting measurement results from the 2005 and was respectively $75315 \mathrm{~m}^{3}$ and $37175 \mathrm{~m}^{3}$. The calculated silting ratio of the main reservoir in its sixteenth year of operation after desilting of the main reservoir was $33 \%$ and the silting ratio of the assistant reservoir in its 
eighteenth year of working was $33 \%$ and $18 \%$ respectively.

Graphical relations between the dimensionless relative sediment deposits $\left(\mathrm{S}_{\mathrm{h}} / \mathrm{S}\right)$ and the relative volumetric capacities of the reservoir $\left(\mathrm{V}_{\mathrm{h}} / \mathrm{V}\right)$ elaborated for both reservoirs - the main and the assistant one - were presented in Figure 2.

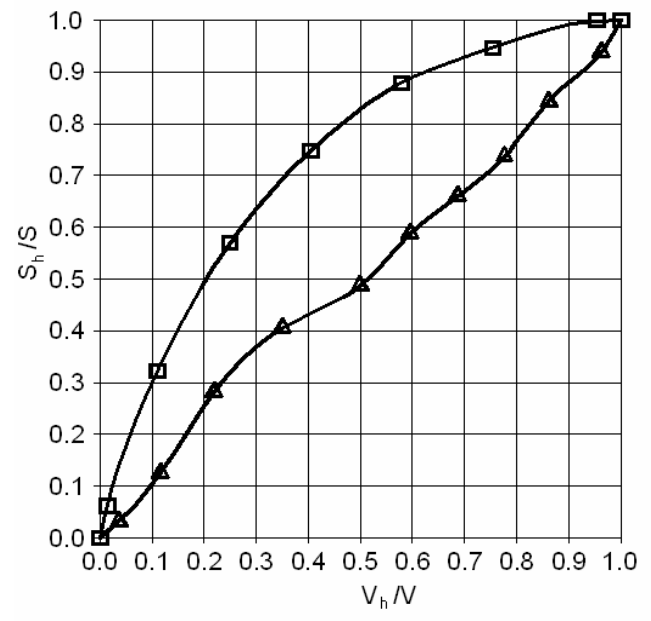

-

FIGURE 2. Horizontal spatial distribution of bottom sediment deposits in the main and assistant reservoir at Zesławice determined according to measurements in the 2005

In the inflow part of the main reservoir much more sediment was accumulated in comparison to the assistant reservoir. According to the elaborated horizontal spatial distribution of bottom sediments (Fig. 2) $58 \%$ of the sediment trapped in the reservoir is accumulated in the main reservoir in its inflow part located between sections $15-15$ and $10-10$, what corresponds with the relative volumes from 0 to 0.25 . In the inflow part of the assistant reservoir of the relative volumetric capacity 0.22 only
$29 \%$ of the volume of sediment trapped in this reservoir was deposited there. The sediment in the assistant reservoir is more evenly distributed starting from the upstream and to the dam as compared with sediment distribution in the main reservoir.

Comparing the horizontal distribution of bottom sediments in the main reservoir in the year 2005 with sediment distribution in this reservoir elaborated by Tarnawski et Słowik-Opoka (2002) basing upon silting measurement results from the 1968 and 1983 it was found that after desilting and directing a part of inflow waters from the River Dłubnia into the assistant reservoir silting of the inflow part decreased only slightly in a comparable period of time of its operation (Fig. 3).

Equally, after two years as well as after seventeen years of operation proceeding desilting of the main reservoir (year 1968

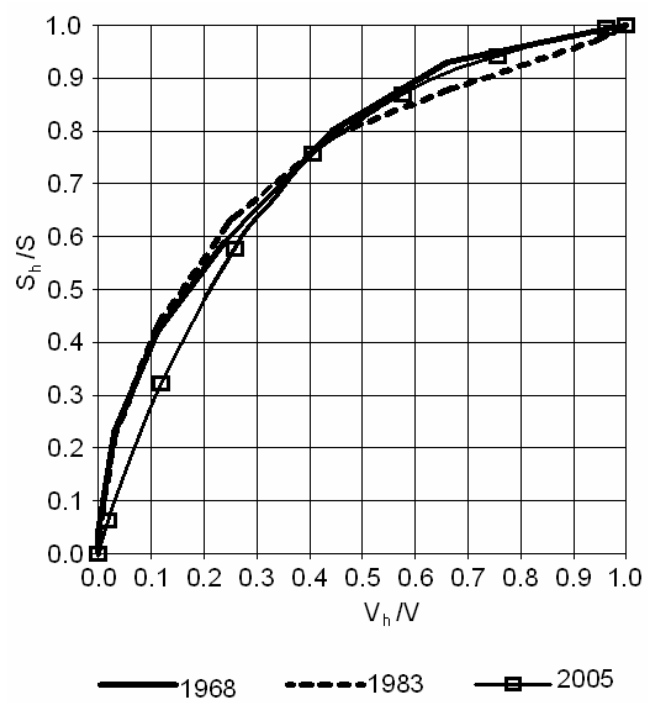

FIGURE 3. Horizontal spatial distribution of bottom sediment deposits at Zesławice before desilting (1968 and 1983) and after desilting (2005) 
and 1983) the volume of the sediment trapped in the inlet part of the reservoir i.e. to section 12-12 (relative volume equal 0.03 ) was respectively 23 and $22 \%$. In the year 2006 i.e. after sixteen years following desilting the relative volume of the sediment trapped in the inflow part of the main reservoir i.e. to the section $12-12$ is almost three times smaller than before desilting (Fig. 3) In consequent cross-sections differences of relative volumes of the sediment trapped in the reservoir before and after desilting are lower and lower, reaching the value zero in the section $8-8$ (relative volume $0.40)$.

Maximal depth of the main and assistant reservoirs was determined on the basis of silting measurements performed in the 2005 end equals respectively 3.01 $\mathrm{m}$ and $1.63 \mathrm{~m}$. The relation between the dimensionless relative volumes of sediment deposits $\left(\mathrm{S}_{\mathrm{v}} / \mathrm{S}\right)$ and the relative depths of the reservoirs $\left(\mathrm{D} / \mathrm{D}_{\mathrm{m}}\right)$ elaborated for the investigated reservoirs are reflected in Figure 4. In the main reservoir sediments formed on isle in the inflow (upstream) part of the reservoir value $\mathrm{S}_{\mathrm{v}} / \mathrm{S}$ equaling 0.09 for $\mathrm{D} / \mathrm{D}_{\mathrm{m}}$ equal zero (Fig. 4). The vertical distribution of sediment in both reservoirs is even but in each of these reservoirs at relative depth $\mathrm{D} / \mathrm{D}_{\mathrm{m}}$ bigger than 0.9 sediment is not accumulated.

A comparison of vertical distribution of bottom sediments in the main reservoir elaborated on the basis of measurements from the 2005 and sediment distribution in this reservoirs, elaborated by Tarnawski and Słowik-Opoka (2002) basing on silting measurements results form the 1968 and 1983, it was found that after desilting silting of shallow zones of the

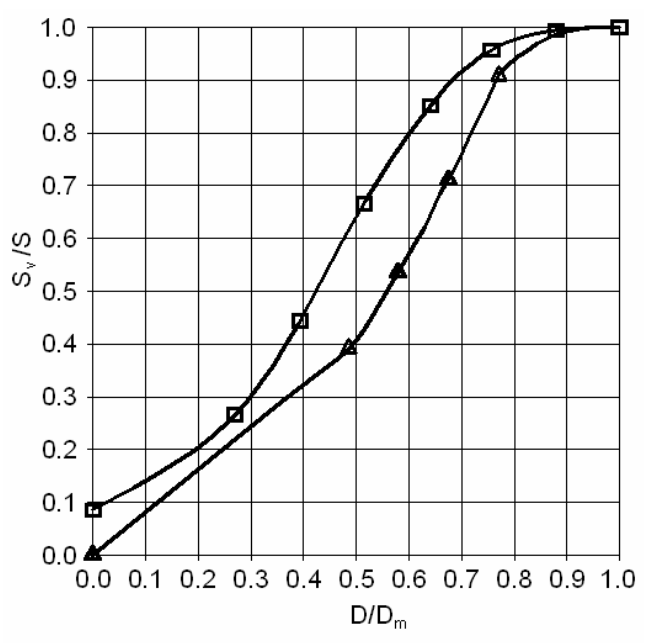

—-assistant reservoir $\square-$ main reservoir

FIGURE 4. Vertical spatial distribution of bottom sediment deposits in the main and assistant water reservoir at Zesławice according to measurements in the 2005

main reservoirs i.e. of relative depths $\mathrm{D} / \mathrm{D}_{\mathrm{m}}$ did not exceed 0.4 (Fig. 5).

\section{CONCLUSIONS}

The water reservoirs at Zesławice are characterized by silting intensity. The silting ratio of the main water reservoir in the 2006 i.e. after seventeen years of operation equaled $33 \%$ and of the assistant reservoir over 19\%. Directing a part of inflowing water and sediment into the building assistant reservoir for the time of the main reservoir desilting contributed to decrease in silting intensity of the main reservoir. The silting ratio of the main reservoir before reconstruction in the 1983 i.e. in the seventeenth year of operation was not quite $51 \%$. Division of water flow into two water reservoirs caused a change of sediment trapping conditions in the main water reservoir. 

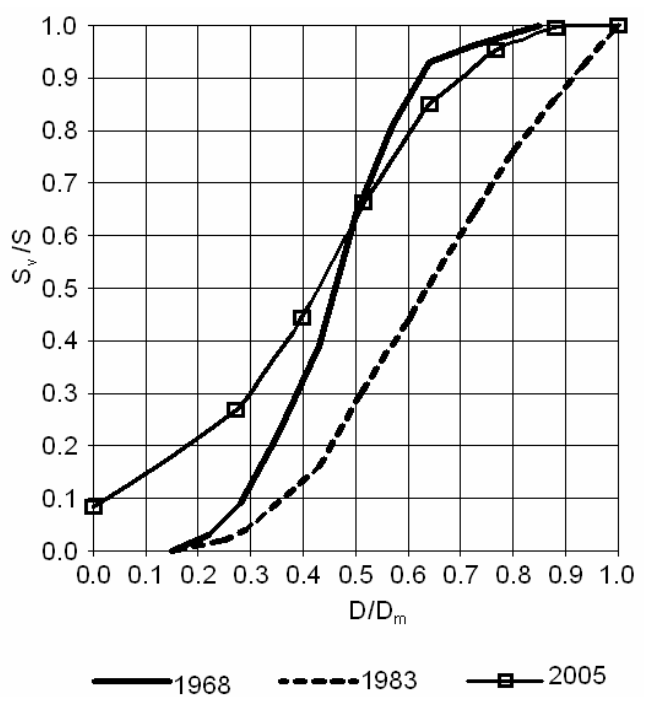

2005

FIGURE 5. Vertical spatial distribution of bottom sediments in the main water reservoir at Zesławice before desilting (1968 and 1983) and after desilting (2005)

In consequence of decreased flow rate of the water inflowing into the main reservoir increase in silting. Sedimentation in the inflow part took place. Determination of the change of spatial distribution of sediment deposits in the investigated water reservoir is possible due to the horizontal sediment deposits distribution in particular years of operation elaborated according to Dendy's method. In the main reservoir over $58 \%$ of sediment is accumulated in the inflow part, whereas, in the assistant reservoir - as it result from horizontal spatial distribution of sediment in this reservoir bottom sediments are distributed evenly on its whole length. In a comparable operation period before desilting (measurement in the 1983) and after desilting (measurement in the 2005) i.e. respectively after seventeen and sixteen years in the main reservoir the accumulated sediments formed an isle - value $\mathrm{S}_{\mathrm{v}} / \mathrm{S}$ equaling 0.09 for $\mathrm{D} / \mathrm{D}_{\mathrm{m}}$ equal zero in consequence of a change of hydraulic conditions of water and sediment flow caused by directing a part of water inflowing from the River Dhubnia to the assistant reservoirs.

\section{REFERENCES}

BATUCA G.D., JORDAAN M.J. JR 2000: Silting and desilting of reservoirs. A.A. Balkema. Rotterdam.

DĄBKOWSKI L., SKIBIŃSKI J., ŻBIKOWSKI A. 1982: Hydrauliczne podstawy projektów wodno-melioracyjnych [The hydraulic bases of water-reclamation projects]. PWRiL, Warszawa.

DENDY F.E. 1974: Sediment trap efficiency of small reservoirs. Trans. Amer. Soc. Agric. Eng., 17, 5, 898-908.

DENDY F.E. 1982: Distribution of sediment deposits in small reservoirs. Trans. Amer. Soc. Agric. Eng., 25, 1, 100-104.

TARNAWSKI M., SŁOWIK-OPOKA E. 2002: Rozkład materiału dennego w zbiorniku w Zesławicach [Distribution of bed material in water reservoir situated in the locality of Zesławice]. Zesz. Nauk. AR $w$ Krakowie, $\mathrm{nr}$ 393, ser. Inżynieria Środowiska, z. 23, 259-266.

Streszczenie: Rozktad przestrzenny osadów dennych $w$ zbiornikach wodnych $w$ Zesławicach. W pracy przedstawiono rozkład przestrzenny osadów w dwóch małych zbiornikach wodnych w Zesławicach na rzece Dłubni według metody Dendy'ego, opracowany na podstawie wyników pomiarów zamulania wykonanych w 2005 roku. Obliczony stopień zamulenia zbiornika głównego w szesnastym roku eksploatacji, po odmuleniu zbiornika głównego, wynosi $33,0 \%$, a stopień zamulenia zbiornika remontowego w osiemnastym roku eksploatacji wynosi $18,8 \%$. Określono poziome i pionowe rozmieszczenie osadów w zbiornikach. Poziome rozmieszczenie osadów określono jako zależność między względną objętością odkładów rumowiska 
$\left(\mathrm{S}_{\mathrm{h}} / \mathrm{S}\right)$ i względną pojemnością zbiornika $\left(\mathrm{V}_{\mathrm{h}} / \mathrm{V}\right)$, a pionowe rozmieszczenie osadów przedstawiono jako zależność względnej objętości odkładów rumowiska $\left(\mathrm{S}_{\mathrm{V}} / \mathrm{S}\right)$ i względnej głębokości zbiornika $\left(\mathrm{D} / \mathrm{D}_{\mathrm{m}}\right)$. Na podstawie analizy poziomego rozmieszczenia osadów stwierdzono, że w zbiorniku głównym w Zesławicach w części wlotowej zbiornika, której objętość względna wynosi 0,25 , zgromadzone jest $58 \%$ rumowiska zatrzymanego w zbiorniku. W części wlotowej zbiornika remontowego o objętości względnej wynoszącej 0,22 , odłożone zostało zaledwie $29 \%$ rumowiska. Porównując krzywe dystrybucji poziomej osadów w zbiorniku głównym w części wlotowej według danych pomiarowych z 2005 i z 1986 roku, tj. z porównywalnego okresu eksploatacji przed odmuleniem i wybudowaniem zbiornika remontowego stwierdzono, że względne objętości rumowiska zatrzymanego po odmuleniu są ponad $40 \%$ większe niż przed odmuleniem. W porównywalnym okresie eksploatacji przed odmuleniem (pomiar w 1983 r.) i po odmuleniu (pomiar w 2005 r.), tj. odpowiednio po siedemnastu i szesnastu latach, w zbiorniku głównym gromadzone osady utworzyły wyspe. Została ona utworzona w wyniku zmiany warunków hydraulicznych przepływu wody i rumowiska, spowodowanych skierowaniem części dopływu wód rzeki Dłubni do zbiornika remontowego, wartość $\mathrm{S}_{\mathrm{V}} / \mathrm{S}$ wynosząca 0,09 dla $\mathrm{D} / \mathrm{D}_{\mathrm{m}}$ równej zero. Stwierdzono, że zmianę rozkładu przestrzennego osadów w badanym zbiorniku wodnym umożliwia opracowany według Dendy'ego poziomy rozkład rumowiska w poszczególnych latach eksploatacji.

\section{MS received March 2009}

\section{Authors' addresses:}

Bogusław Michalec

Mateusz Strutyński

Department of Water Engineering Agriculture University in Cracow Al. A. Mickiewicza 24/28

30-059 Cracow

e-mail: rmmichbo@cyf-kr.edu.pl

e-mail:mstrutynski@ar.krakow.pl

Karol Pęczek

FWK-Air Sp.z.o.o.

31-553 Kraków

ul. Cystersów 13

e-mail:karol.peczek@interia.pl 